Journal of Telenursing (JOTING)

Volume 3, Nomor 1, Juni 2021

e-ISSN: 2684-8988

p-ISSN: 2684-8996

DOI: https://doi.org/10.31539/joting.v3i1.2091

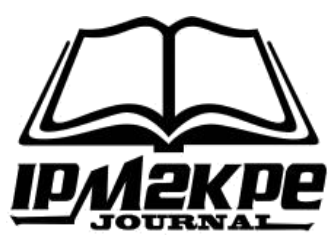

\title{
PRAKTIK PEMBERIAN MAKANAN DAN PRAKTIK KESEHATAN DENGAN KEJADIAN BALITA DENGAN GIZI KURANG
}

\author{
Siti Gabena Sir ${ }^{1}$, Evawany Y. Aritonang ${ }^{2}$, Jumirah $^{3}$ \\ Universitas Sumatera Utara ${ }^{1,2,3}$ \\ gabenasiti@gmail.com ${ }^{1}$
}

\begin{abstract}
ABSTRAK
Penelitian ini bertujuan untuk mengetahui hubungan praktik pemberian makanan dan praktik kesehatan pada balita yang memiliki status gizi kurang di Desa Sekip, Kecamatan Lubuk Pakam, Kabupaten Deli Serdang. Penelitian ini menggunakan pendekatan cross sectional dengan jumlah sampel 100 responden. Pengambilan sampel menggunakan teknik kluster dan teknik acak sederhana (gulungan kertas). Data yang dihasilkan dianalisis secara univariat dan bivariat dengan menggunakan uji chi-square $(\alpha=0,05)$. Hasil penelitian menunjukkan balita yang mengalami kejadian kurang gizi sebanyak 34\% sedangkan praktik pemberian makan dan praktik kesehatan yang diterapkan ibu kepada anak balita sebagian dikategorikan tidak baik yaitu 56 orang (56\%) dan 54 orang (54\%). Simpulan ada hubungan antara praktik pemberian makan dan praktik kesehatan terhadap gizi kurang pada balita.
\end{abstract}

Kata Kunci: Balita, Gizi Kurang, Praktik Kesehatan, Praktik Pemberian Makan

\section{ABSTRACT}

This study aims to determine the relationship between feeding practices and health practices for under-five children with malnutrition in Sekip Village, Lubuk Pakam District, Deli Serdang Regency. This study used a cross-sectional approach with a sample size of 100 respondents. Sampling was done using cluster technique and simple random technique (roll of paper). The resulting data were analyzed univariate and bivariate using the chi-square test $(\alpha=0.05)$. The results showed that under-fives who experienced malnutrition were 34\%. Simultaneously, mothers' feeding practices and health practices to children under-five were partly categorized as bad, namely 56 people (56\%) and 54 people (54\%). In conclusion, there is a relationship between feeding practices and health practices on undernutrition in children under-five.

Keywords: Toddler, Malnutrition, Health Practices, Feeding Practices

\section{PENDAHULUAN}

Balita merupakan sekelompok umur yang rentan terhadap penyakit dan paling banyak mengidap penyakit dalam kasus kekurangan gizi. Pada umur $<5$ tahun, anak mengalami pertumbuhan dan perkembangan yang cepat baik pada fisik maupun otak. Dalam pertumbuhan dan perkembangan yang dialami, balita membutuhkan perhatian yang serius dalam asupan gizi yang tinggi dan seimbang agar nutrisi yang dibutuhkan oleh tubuh menjadi terpenuhi. Sebab balita belum memiliki kemampuan kognitif yang dapat mengetahui makanan yang baik dan benar untuk dikonsumsi oleh tubuh. 
Kekurangan gizi yang dialami pada masa ini akan menghambat pertumbuhan dan perkembangan balita hingga dewasa dan bersifat irreversible. Akibatnya anak akan mengalami gagal tumbuh sehingga memiliki ukuran tubuh seperti tinggi badan yang tidak sesuai dengan umurnya (Jawad et al., 2018).

Malnutrisi atau gizi kurang merupakan kondisi seseorang yang memiliki nutrisi dibawah angka rata-rata. Gizi kurang disebabkan karena seseorang kekurangan asupan karbihidrat, protein, lemak dan vitamin yang sangat dibutuhkan oleh tubuh. Secara patofisiologi, gizi kurang atau gizi buruk pada balita yaitu mengalami kukurangan energi protein, anemia gizi besi, gangguan akibat kurangnya Iodium dan kurang vitamin A. Kurangnya asupan empat sumber tersebut pada balita menyebabkan terjadinya pertumbuhan dan perkembangan terhambat, daya tahan tubuh menurun, tingkat kecerdasan yang rendah, kemampuan fisik menurun, terjadinya gangguan pertumbuhan jasmani dan mental, stunting serta yang paling terburuknya yaitu kematian pada balita (Alamsyah et al., 2017).

Gizi kurang pada balita disebabkan oleh beberapa faktor yang dibagi menjadi dua yaitu faktor langsung dan faktor tidak langsung. Faktor langsung disebabkan oleh penyakit infeksi dan asupan gizi sedangkan faktor tidak langsung disebabkan oleh status ekonomi, pola asuh dan pengetahuan ibu. Pola asuh dan pengetahuan ibu dalam mengurus anak memiliki peran yang penting dalam hal memberikan makan pada anak maupun pengetahuan tentang jenis makanan yang akan diberikan sesuai umur dan kebutuhannya, praktik kesehatan serta memberi kasih sayang (Puspa \& Rahmawati, 2020). Berdasarkan penelitian yang dilakukan oleh Mitra et al., (2019), hasil menunjukkan bahwa sebanyak 52,7\% balita mengkonsumsi 4 sampai 5 jenis makanan dan $18,0 \%$ balita hanya mengkonsumsi kurang dari 3 jenis makanan. Hal ini menunjukkan bahwa jenis makanan yang di konsumsi oleh balita belum terlalu beragam dan mencukupi nutrisi yang dibutuhkan oleh tubuh.

Masalah gizi kurang dapat diatasi dengan cara praktik pemberian makanan dan kesehatan untuk balita yang bertujuan agar memulihkan dan memperbaiki gizi serta membentuk kebiasaan makan balita di masa dewasa. Pemberian menu makanan yang baik untuk balita akan membantu ibu dalam melakukan pendidikan gizi dengan cara memanfaatkan imajinasi balita untuk meningkatkan nafsu makan. Bentuk dari makanan yang disajikan dapat mempengaruhi selera makan pada balita seperti memberikan variasi warna pada makanan, menghindari makanan yang menyulitkan mereka seperti bertulang banyak, pilih makanan yang lunak, mudah diolah dan bergizi tinggi (Akbar et al., 2021). Berdasarkan uraian tersebut, maka penelitian ini dilakukan untuk memberikan praktik pemberian makanan dan praktik kesehatan pada balita yang memiliki status gizi kurang.

\section{METODE PENELITIAN}

Jenis penelitian ini merupakan survei dengan pendekatan cross sectional. Populasi dalam penelitian ini adalah ibu mempunyai balita di Desa Sekip Kecamatan Lubuk Pakam Kabupaten Deli Serdang. Tehnik pengambilan sampel berdasarkan teknik kluster bertahap yaitu dengan menentukan dusun sebagai kluster pada tahap pertama. Tahap selanjutnya menentukan rumah tangga yang dijadikan anggota sampel. Besarnya dusun yang diambil adalah 30\% dari jumlah dusun di Desa Sekip Kecamatan Lubuk Pakam Kabupaten Deli Serdang. Selanjutnya jumlah dusun yang diambil sebanyak 5 dusun, dengan teknik acak sederhana (gulungan kertas). Selanjutnya dari 5 dusun ditentukan besar rumah tangga secara proporsional to size sehingga di hasilkan 100 responden. 
Pengambilan data melalui kuesioner dan pengukuran antropometri. Uji statistik yang digunakan adalah uji korelasi chi-square dengan menggunakan taraf signifikansi 5\% $(\alpha$ $=0,05)$.

\section{HASIL PENELITIAN}

Tabel. 1

Distribusi Kejadian Kurang Gizi Anak Balita di Desa Sekip

Kecamatan Lubuk Pakam Kabupaten Deli Serdang

\begin{tabular}{ccc}
\hline Kejadian Kurang Gizi & N & $\%$ \\
\hline Ya & 34 & 34,0 \\
Tidak & 66 & 66,0 \\
\hline Total & 100 & 100,0
\end{tabular}

Berdasarkan tabel 1 didapatkan data balita yang mengalami kejadian kurang gizi sebanyak 34\% di Desa Sekip Kecamatan Lubuk Pakam Kabupaten Deli Serdang.

Tabel. 2

Hubungan antara Praktik Pemberian Makanan dan Praktik Kesehatan dengan Kejadian Kurang Gizi Anak Balita di Desa Sekip Kecamatan Lubuk Pakam Kabupaten Deli Serdang

\begin{tabular}{|c|c|c|c|c|c|c|c|c|}
\hline \multirow{3}{*}{ No } & \multirow{3}{*}{$\begin{array}{c}\text { Praktik } \\
\text { Pemberian } \\
\text { Makan }\end{array}$} & \multicolumn{4}{|c|}{ Kejadian Kurang Gizi } & \multicolumn{2}{|c|}{ Total } & \multirow{3}{*}{$P$} \\
\hline & & \multicolumn{2}{|c|}{ Tidak } & \multicolumn{2}{|c|}{$\mathrm{Ya}$} & \multirow{2}{*}{$\mathrm{n}$} & \multirow{2}{*}{$\%$} & \\
\hline & & $\mathrm{N}$ & $\%$ & $\mathrm{n}$ & $\%$ & & & \\
\hline 1. & Baik & 39 & 88,6 & 5 & 11,4 & 44 & 100 & \multirow{2}{*}{0,000} \\
\hline \multirow[t]{2}{*}{2.} & Tidak baik & 27 & 48,2 & 29 & 51,8 & 56 & 100 & \\
\hline & $\begin{array}{c}\text { Praktik } \\
\text { Kesehatan }\end{array}$ & & & & & & & \\
\hline 1. & Baik & 40 & 87,0 & 6 & 13,0 & 46 & 100 & 0,000 \\
\hline 2. & Tidak baik & 26 & 48,1 & 28 & 51,9 & 54 & 100 & \\
\hline
\end{tabular}

Berdasarkan tabel 2, data menunjukkan bahwa praktik pemberian makan dan praktik kesehatan yang diterapkan ibu kepada anak balita sebagian dikategorikan tidak baik yaitu masing-masing 56 orang (56\%) dan 54 orang (54\%).

\section{PEMBAHASAN}

Status gizi pada balita mempengaruhi pertumbuhan fisiknya berdasarkan tiga indikator yaitu berat badan menurut umur $(\mathrm{BB} / \mathrm{U})$, tinggi badan menurut umur $(\mathrm{TB} / \mathrm{U})$ dan berat badan menurut tinggi badan $(\mathrm{BB} / \mathrm{TB})$. Ketiga indikator tersebut memiliki standar baku dari Badan Kesehatan Dunia ataupun dari standar yang ditetapkan oleh Kementrian Kesehatan. Untuk indikator berat badan dapat naik, tetap maupun turun yang berbeda dengan indikator tinggi badan yang hanya bisa naik ataupun tetap pada kurun waktu tertentu. Dalam keadaan normal, tinggi badan tumbuh seiring pertambahannya umur anak tergantung dengan pola asuh ibu dan gizi yang diberikan untuk dikounsumsi. Tinggi badan dapat merefleksikan riwayat gizi yang dikonsumsi sejak dini dan bersifat kurang sensitif terhadap perubahan gizi yang masuk. Pola pengasuhan anak pada masing-masing keluarga memiliki cara yang berbeda-beda. Hal ini dipengaruhi oleh beberapa faktor yaitu latar belakang pendidikan ibu, pekerjaan ibu, status gizi ibu dan jumlah anak dalam keluarga (Aghnita et al., 2017). 
Berdasarkan hasil penelitian pada tabel 1 dari 100 responden yang menunjukkan bahwa dari 34 balita masih berstatus kejadian kurang gizi sebanyak 34\% sementara yang memiliki status gizi normal sebanyak 66 balita (66\%). Hal ini menunjukkan ratarata asupan energi, protein, lemak dan karbohidrat pada responden termasuk kedalam kategori kurang dari angka kecukupan gizi. Menurut Aghnita et al., (2017) asupan gizi yang kurang pada makanan yang diperoleh balita disebabkan karena tingkat pengetahuan dan kesadaran ibu yang kurang dalam menentukan dan memberikan makanan untuk balitanya. Pengetahuan yang dimiliki ibu dapat mempengaruhi tindakan ibu yang diperoleh dari jenjang pendidikan yang diharapkan akan menjadi perubahan perilaku gizi. Asupan gizi yang kurang pada balita menunjukkan pola makanan yang dikonsumsi tidak tepat.

Adapun hasil penelitian Supriatna \& Muliawati (2018) yang membahas tentang faktor yang mempengaruhi gizi kurang pada balita yaitu sebanyak 30 responden $(52,6 \%)$ hanya menempuh pendidik Sekolah Dasar (SD) yang menyebabkan pola asuh anak yang rendah sehingga berpengaruh terhadap gizi anak. Pendidikan orang tua yang rendah membuat kurang pedulinya dan tidak tahu hal-hal yang dibutuhkan oleh anak untuk tumbuh kembangnya. Pekerjaan orang tua juga memiliki pengaruh yang besar dalam pemberian gizi balita $(80,7 \%)$. Kondisi perekonomian yang rendah akan memiliki kesulitan dalam memenuhi kebutuhan anak seperti makanan pokok sehari-hari, vitamin, sayuran dan buah-buahan. Mustika \& Syamsul (2018) berpendapat bahwa pemberian ASI eksklusif pada anak waktu bayi tidak berdampak terlalu besar pada status gizi balita karena status gizi yang kurang pada saat bayi dapat diatasi dengan cara memberikan Makanan Pendamping ASI (MP-ASI) oleh petugas kesehatan yang optimal untuk menjaring balita yang mengalami kejadian kurang gizi.

Hal ini didukung oleh penelitian Kurdaningsih (2018) yang melihat hubungan pemberian MP-ASI pada balita 6-24 bulan dengan status gizi. Dari hasil penelitian tersebut diketahui bahwa 36 bayi yang menunjukkan bahwa dari 25 bayi tidak di berikan MP-ASI sebanyak $7(28,0 \%)$ sementara yang diberikan MP-ASI sebanyak 18 $(72,0 \%)$ sedangkan bayi yang memiliki status gizi buruk sebanyak 11 bayi yang tidak diberikan MP-ASI sebanyak 8 (72,7\%) sementara yang diberikan MP-ASI sebanyak 3 $(27,3 \%)$. Berdasarkan hasil uji statistik menggunakan Chi-Square diperoleh nilai pvalue 0,032 yang berarti adanya hubungan antara pemberikan MP-ASI dengan status gizi balita.

Ketika bayi lebih dini diperkenalkan dengan MP-ASI, maka selanjutnya bisa jadi bayi memiliki pola makan yang tidak sesuai dengan tubuhnya kebutuhan energinya. Bayi akan terbiasa dengan makan banyak atau berlebihan. Inilah yang membuat bayi berisiko menjadi gemuk atau obesitas. Mekanisme mengenai obesitas karena pemberian MP-ASI dapat terjadi karena peningkatan asupan kalori dan protein dari makanan pendamping yang dapat menyebabkan terjadinya peningkatan berat badan dan persentase lemak dalam tubuh anak. Pemberian MP-ASI dini dapat menyebabkan terjadinya premature termination of breastfeeding (Wang et al., 2017).

Salah satu pakar kesehatan mengatakan bahwa pengenalan makanan padat atau MP-ASI pada balita akan berisiko pada obesitas yang disebabkan oleh tidak tepatnya masa pemberian makanan pendamping ASI. Saat umur anak belum menginjak 6 bulan, peningkatan resiko obesitas bisa saja terjadi karena adanya peningkatan lemak yang terjadi di dalam tubuh dan mengendap sehingga terjadinya kelebihan berat badan pada anak (Symon et al., 2017). 
Berdasarkan tabel 2 hasil uji statistik yang menggunakan Chi-Square diperoleh nilai p-value pada praktik pemberian makan 0,000 dan praktik kesehatan 0,000 . Hal ini menunjukkan bahwa adanya hubungan antara praktik pemberian makan dan praktik kesehatan terhadap gizi kurang pada balita. Hal ini sejalan dengan penelitian Puspa \& Rahmawati (2020) tentang praktik pemberian makan dan perawatan kesehatan anak di kelompok bermain Al Azhar 1. Hasil penelitian menunjukkan adanya hubungan antara praktik pemberian makan dan perawatan kesehatan pada anak. Sebanyak 64\% anak lebih banyak diasuh ibu dan $44 \%$ anak disiapkan makanannya oleh ibu. Hampir $84 \%$ anak kadang-kadang masih disuapi dan $16 \%$ anak selalu makan disuapi. Alasan ibu masih menyuapi anaknya karena adanya kekhawatiran pada anak jika makan sendiri justru makanannya tidak dimakan dan tempat makannya menjadi kotor. Praktik kesehatan yang dilakukan pada penelitian ini yaitu $72 \%$ anak cuci kaki sebelum tidur, $56 \%$ sikat gigi, $72 \%$ buang air besar menggunakan air dan sabun.

Selain makan yang disuapi, penjadwalan menu makan juga sangat penting bagi anak. Modifikasi makanan adalah cara merubah bentuk dan rasa makanan dari yang kurang menarik menjadi lebih menarik dan menampilkan bentuk yang lebih bagus dari aslinya. Modifikasi resep keluarga dalam meningkatkan nafsu makan anak adalah memperhatikan variasi makanan agar anak tidak bosan dalam pemenuhan nutrisi. Variasi makanan adalah susunan menu yang dihidangkan secara menarik dengan memperhatikan rasa, warna, bentuk, tekstur dan susunan makanan yang dibuat.

Hasil penelitian Akbar et al., (2021) tentang modifikasi makanan untuk meningkatkan gizi balita menunjukkan hasil pre-test dan post-test modifikasi makanan pada kelompok perlakuan adanya sedikit peningkatan. Hasil pre-test modifikasi makanan pada masalah penyajian makan di kelompok perlakuan didapatkan 20 responden $(60,0 \%)$, setelah dilakukan modifikasi hasil post-test yang didapatkan 14 responden $(39,6 \%)$. Kemudian permasalahan penyusunan menu hasil pre-test didapatkan sebanyak 8 responden $(25,5 \%)$, setelah dilakukan modifikasi hasil post-test menjadi 3 responden $(8 \%)$. Adapun permasalahan ketiga yaitu pengolahan makan, hasil pre-test sebanyak 4 responden (7\%), setelah dilakukan modifikasi hasil post-test menjadi 3 responden (8\%). Permasalahan terakhir ialah cara pemberian makanan pada anak sebanyak 3 responden (8\%) pada saat post-test menjadi $0(0 \%)$. Dengan demikian, dapat disimpulkan bahwa ada hubungan yang signifikan antara modifikasi makanan (penyusunan menu, pengolahan makanan, penyajian makanan dan cara pemberian makan) terhadap gizi balita.

Kasus balita gizi kurang banyak ditemukan pada keluarga dengan jumlah anggota keluarga yang besar dibandingkan dengan keluarga kecil. Keluarga dengan jumlah anak yang banyak dan jarak kelahiran yang sangat dekat akan menimbulkan banyak masalah, yakni pendapatan keluarga yang paspasan, sedangkan anak banyak maka pemerataan dan kecukupan makan didlam keluarga akan sulit dipenuhi. Anak yang lebih kecil akan mendapat jatah makanan yang lebih sedikit, karena makanan lebih banyak diberikan kepada kakak mereka yang lebih besar, sehingga mereka menjadi kurang gizi dan rawan terkena penyakit (Mustika \& Syamsul, 2018).

\section{SIMPULAN}

Ada hubungan antara praktik pemberian makan dan praktik kesehatan terhadap gizi kurang pada balita. 


\section{SARAN}

Diharapkan dapat dimanfaatkan menjadi salah satu media pembelajaran dan pengetahuan untuk melakukan penelitian lanjutan mengenai gizi kurang pada balita, adanya tenaga kesehatan yang terjun kelapangan dan ikut andil dalam memberikan edukasi pada masyarakat awam berupa penyuluhan tentang gizi kurang pada daerahdaerah yang masih terjangkit yang merupakan sebagai bentuk pencegahan dan diharapkan adanya petugas kesehatan yang memantau pertumbuhan dan perkembangan balita dan memberikan himbauan kepada masyarakat untuk rajin ke posyandu sehingga kejadian gizi kurang dapat terdeteksi sejak dini dan mengurangi angka gizi kurang.

\section{DAFTAR PUSTAKA}

Aghnita, K. A., Wahyu, T., \& Suryani, D. (2017). Asupan Zat Gizi dan Status Kesehatan pada Balita yang Mendapatkan PMT-P. Jurnal Media Kesehatan, 10(1), 89-97. https://doi.org/10.33088/jmk.v10i1.329

Akbar, F., Ambohamsah, I., \& Amelia, R. (2021). Modifikasi Makanan untuk Meningkatkan Gizi Balita di Kabupaten Polewali Mandar. Jurnal Kesehatan Kusuma Husada, 3(1), 94-102. https://doi.org/10.34035/jk.v12i1.614

Alamsyah, D., Mexitalia, M., Margawati, A., Hadisaputro, S., \& Setyawan, H. (2017). Beberapa Faktor Risiko Gizi Kurang dan Gizi Buruk pada Balita 12-59 Bulan (Studi Kasus di Kota Pontianak). Jurnal Epidemiologi Kesehatan Komunitas, 2(1), 46-53. https://doi.org/10.14710/jekk.v2i1.3994

Jawad, I. H., Al-Jubori, K. H., \& Baiee, H. A. (2018). Prevalence and Associated Factors of Under Nutrition Among Under-Five Children in Babylon Province, Iraq, 2016. Journal of University of Babylon for Pure and Applied Sciences, 26(3), 123-153. https://doi.org/10.5958/0974-360X.2017.00363.8

Kurdaningsih, S. V. (2018). Hubungan Pemberian Makanan Pendamping dengan Status Gizi pada Balita Usia 6-24 Bulan. Jurnal Ilmiah Multi Science Kesehatan, 9(1), 109-115. https://doi.org/10.36729/bi.v9i1.124

Mitra, M., Septiani, W., Susmaneli, H., \& Nurlisis, N. (2019). Meningkatkan Status Gizi Balita Melalui Praktek Pengolahan Makanan Pendamping ASI Buatan Sendiri. Dinamisia: Jurnal Pengabdian Kepada Masyarakat, 3(2), 208-213. https://doi.org/10.31849/dinamisia.v3i0.4169

Mustika, W., \& Syamsul, D. (2018). Analisis Permasalahan Status Gizi Kurang pada Balita di Puskesmas Teupah Selatan Kabupaten Simeuleu. Jurnal Kesehatan Global, 1(3), 127-136. https://doi.org/10.33085/jkg.v1i3.3952

Puspa, A. R., \& Rahmawati, L. A. (2020). Praktik Pemberian Makan dan Perawatan Kesehatan Anak di Kelompok Bermain Al Azhar 1. Jurnal Al-Azhar Indonesia Seri Sains dan Teknologi, 5(3), 136-143. https://doi.org/10.36722/sst.v5i3.376

Supriatna, N. K., \& Muliawati, D. (2018). Faktor yang Mempengaruhi Gizi Kurang Balita di Desa Kepek dan Karang Tengah Wonosari Gunungkidul Yogyakarta. Jurnal Kesehatan Madani Medika, 9(1), 7-14. https://doi.org/10.36569/jmm.v9i1.27

Symon, B., Crichton, G. E., \& Muhlhausler, B. (2017). Does the Early Introduction of Solids Promote Obesity? Singapore Medical Journal, 58(11), 626-631. https://doi.org/10.11622/smedj.2017024

Wang, Y., Min, J., Khuri, J., \& Li, M. (2017). A Systematic Examination of the Association between Parental and Child Obesity Across Countries. American Society for Nutrition, 8(1), 436-448. https://doi.org/10.3945/an.116.013235 